\title{
EFFECTIVENESS OF EMBRYO TRANSFER IN COWS - RISK FACTORS INCLUDING IN VIVO DERIVED AND IN VITRO PRODUCED EMBRYOS
}

Maria Wieczorkiewicz ${ }^{1}$, Jędrzej M. Jaśkowski², Agnieszka Wichtowska', Monika OlszewskaTomczyk $^{2}$, Bartłomiej M. Jaśkowski ${ }^{3}$

\begin{abstract}
Multiple Ovulation Embryo Transfer is a biotech method with more than 50 years of history and an established position in cattle breeding. This procedure is beneficial in many ways, but it also carries a risk of failure. The study presents the overview of the most important risk factors that may affect conception rates in the course of embryo transfer, including the factors associated with the embryo sourcing (embryo production method, embryo quality, development stage and breed, embryo storage method), embryo transfer procedure (synchrony/asynchrony, embryo transfer difficulty, the time of the transcervical insemination gun passage, depth of embryo deposition, localization and structure of the corpus luteum relative to the follicle and both individual characteristics of donors and recipients (level of concentration of progesterone, the state of health of the udder, lactation level, body condition score and age) and some environmental factors.
\end{abstract}

Running title: Risk factors for embryo transfer in cows

Keywords: embryo transfer, cattle reproduction, assisted reproduction techniques

\footnotetext{
${ }^{1}$ Department of Basic and Preclinical Sciences, Institute of Veterinary Medicine, Faculty of Biological and Veterinary Sciences, Nicolaus Copernicus University, Toruń, Poland

${ }^{2}$ Department of Clinical Sciences and Diagnostics, Institute of Veterinary Medicine, Faculty of Biological and Veterinary Sciences, Nicolaus Copernicus University, Toruń, Poland

${ }^{3}$ Department of Reproduction and Clinic of Farm Animals, Faculty of Veterinary Medicine, Wroclaw University of Environmental and Life Sciences, Wrocław, Poland

*Correspondence: maria.wieczorkiewicz@umk.pl

Full list of author information is available at the end of article
} 


\section{Introduction}

Multiple Ovulation Embryo Transfer (MOET) is a biotech method with more than 50 years of history and an established position in cattle breeding. The advantages of this method include the possibility to use the genetic potential of valuable mothers, rapid valuation of bulls, creation of genetic reserves of disappearing cattle breeds and elimination of many infectious diseases [1,2]. Approximately 1 million of embryos are transmitted annually around the world. In the EU countries this number is about 140 thousand [3]. Every embryo transfer procedure carries the risk of failure. Under these conditions, any action aimed to reduce this danger to an acceptable level and increase the conception rate (CR) in recipients is fully justified. The study presents the overview of the most important individual and environmental risk factors that may affect CR in the course of embryo transfer.

\section{Factors associated with the embryo sourcing}

Conventional in vivo embryo deriving (IVD) is a technique used for decades. On the other hand, the following increase in in vitro embryo production (IVP) is a result of improvement in the technique of obtaining cumulus oocyte complexes (COC), as well as in vitro maturation (IVM), in vitro fertilization (IVM) and in vitro culture (IVC) [4]. Recently, numerous comparative studies on the efficiency of IVD and IVP embryos transfer have been conducted. Recorded pregnancy rates were lower in the group of recipients receiving IVP embryos than in the females after IVD embryo transfer (Tab. 1) [5]. These results were confirmed by Ferraz et al. [6] with conception rates higher in case of IVD embryo transfer than IVP - both fresh and frozen (49.3 vs. 39\%). Significantly lower, not exceeding $30.9 \%$, results of fertilization after IVP embryo transfer were also observed by Feres et al [4]

The best quality embryos guarantee the highest effectiveness of ET [6-9]. Lindner and Wright [10] reported that after transfer of the IVD embryos, which were evaluated as excellent, good or sufficient quality, pregnancy was obtained in respectively: $45 \%, 44 \%, 27 \%$ of recipients. This dependence was confirmed by Znaniecki, who by transferring high quality embryos reached $60 \%$ of pregnancy rate, while the transfer of good or sufficient quality embryos allowed to fertilize adequately: $43.8 \%$ and $26.1 \%$ of heifers [11]. The newer studies confirm this correlation in both dairy and meat cattle (Tab. 1) [12-14]. The probability of conception after the transfer of poor quality embryos was even $31 \%$ lower than in the case of 1st class embryos [9]. Spell et al. and Roper et al. do not attribute any significant effect of the embryo quality on CR in recipients $[15,16]$.

The effectiveness of embryo transfer is also determined by the stage of their development. Em- bryo transfer of 6- 8-day-old embryos ensured higher pregnancy rates than 5-day and 9-day-old [17]. According to Znaniecki et al. a higher CR was observed in the case a transfer of blastocyst than morula (53.8\% vs. $46.2 \%)$ [18]. A similar dependence was observed by Hasler. The percentage of pregnant females after application of frozen embryos in the morula stage was $54.3 \%$ and in the early blastocyst stage 59.7\% [19]. In the newest studies by Ferraz et al. [6] and Erdem et al. [14] a significantly higher probability of pregnancies after embryo transfer in the expanding blastocyst stage than in the blastocyst, early blastocyst and morula stage were recorded (Tab. 1). The effects of embryo transfer with a reduced number of cells, so called demi- embryos, was also studied. This method allows doubling the number of transferred germs. As a result, despite the lower CR compared to conventional embryo transfer (36.3 vs. 57.7), due to the possibility of fertilization twice as many cows, it is an interesting alternative in the case of a limited number of available embryos. However, some researchers do not attribute any significant influence of the embryo development stage on the results of conception rates in recipients $[15,16]$.

Different CR are also recorded depending on the genetic origin of the transferred embryo [20,21]. Significantly higher results were recorded in the case of transfer the embryos obtained from meat cows, among which the best values were noted in such breeds as: Hereford, Charolaise, Angus and Brangus (Tab.1).

A transfer of frozen embryos results in a slightly lower CR than the transfer of fresh embryos. Ferraz et al. recorded a significant fall in conception rates $(12.5 \%$ and $6.1 \%$ ) in case of frozen IVD and IVP embryos compared to the transfer of fresh ones (Tab. 1)[6]. Alternate results were noted by Rodrigues et al. and Roper et al., who, by transferring fresh or frozen in vitro-produced embryos, did not report any significant effect of this variable on CR in recipients $[9,16]$. The data provided by Do show that the transfer of IVP vitrified embryos did not cause any deterioration of the conception rates compared to the transfer of fresh embryos. On the 35th day after the transfer of fresh embryos, pregnancy was found in $41.3 \%$ of recipients, while after the transfer of vitrified embryos it was found in $40 \%$ [22].

The use of modern technologies has made it possible to select embryos. However, manipulations carried out on semen used for the production of IVF embryos contributed to the reduction of CR in recipients. It was shown that the procedure of sperm sexing using flow cytometry may inhibit the process of gametes capaciation, indirectly lowering the rate of blastocyst development and negatively influencing CR [23,24]. Mikkola et al., comparing the effectiveness of fresh and frozen embryos transfer 
obtained after insemination by sexed semen with conventionally produced germs, proved both significant decrease in the probability of pregnancy after sorted embryo transfer and a negative effect of vitrification on the results of CR (Tab. 1) [24]. Similarly, Sanches et al. transferred the embryos produced from sorted semen and noted that both these processes significantly reduce the probability of pregnancy in recipients [25]. It was found, however, that the negative effects of vitrification can be minimized by using the original protocol for direct transfer of frozen embryos. The results of conception were $51 \%$ for fresh embryos and $35 \%$ and $40 \%$ for vitrified and frozen embryos - directly transferred. Gutnisky et al. also reported that using the commercial Cryotech Vitrification Kit to freeze IVP embryos, the same CR were obtained as after the transfer of fresh embryos produced in the same way $(\mathrm{P} / \mathrm{ET}=46.8 \%)[26]$.

Initially, when cytometric sorting of gametes was not available, the sex of embryos was determined by their biopsy $[27,28]$. Currently, the biopsy of commercially produced IVF embryos is mainly used to evaluate their breeding potential on the basis of biological markers present in the genome [29]. Olivei- ra et al. determined whether the biopsied embryos are capable of implantation and whether these manipulations affect the various stages of pregnancy development. CR was evaluated three times during pregnancy, both in the group of biopsied embryos' recipients (group $B, n=103$ ) and the control group in which transferred embryos were not subjected to the abovementioned treatments (group $\mathrm{C}, \mathrm{n}=82$ ). In the first month of pregnancy the conception rates in the study group decreased in comparison with the control group ( $\mathrm{B}=50.9 \%$ vs. $\mathrm{C}=62.5 \%)$. Pregnancy rates in the 3rd and 8th month were respectively: $\mathrm{B}=50.9 \%$ vs. $\mathrm{C}=47.6 \%$ and $\mathrm{B}=49.6 \%$ vs. $\mathrm{C}=45.2 \%$. Birth rates recorded at $47.1 \%$ in group B and $42.0 \%$ in group C. It was found that embryos manipulation may cause their developmental incompetence and consequently disturbances in the implantation process and loss of pregnancy [29]. In turn, results presented by de Sousa et al. show that this technology can be successfully used in commercial programs aimed at associating assisted reproduction technology with genomic selection, because biopsy violation of the continuity of a pellucid zone produced both in vivo and in vitro has no significant effect on the conception rates (Tab. 1) [30].

TABLE 1 Effects of factors related to in vivo or in vitro embryo production on conception rates (own compilation based on: ${ }^{1}$ Pontes et al [5], ${ }^{2}$ Ferraz et al [6], ${ }^{3}$ Donaldson et al [21], ${ }^{4}$ Arreseigor et al [20], ${ }^{5}$ Mikola et al [24], ${ }^{6}$ De Sousa et al [30])

\begin{tabular}{|c|c|c|}
\hline FACTOR & $\begin{array}{c}\text { CR FOR THE TRANSFER } \\
\text { OF EMBRYOS PRODUCED } \\
I N \text { VIVO }\end{array}$ & $\begin{array}{c}\text { CR FOR THE TRANSFER } \\
\text { OF EMBRYOS PRODUCED } \\
I N \text { VITRO }\end{array}$ \\
\hline Embryo production method ${ }^{1}$ & 41.5 & 33.5 \\
\hline \multicolumn{3}{|l|}{ Embryo quality $^{2}$} \\
\hline Excelent & 42.2 & \\
\hline Good & 32.8 & \\
\hline Sufficient & 23.7 & \\
\hline \multicolumn{3}{|l|}{ Embryo development stage $^{2}$} \\
\hline Morula & 36.5 & \\
\hline early blastocyst & 38.1 & \\
\hline Blastocyst & 45.3 & \\
\hline \multicolumn{3}{|l|}{ Embryo breed ${ }^{3,4}$} \\
\hline Brangus $^{3,4}$ & 47 & 36.8 \\
\hline Angus $^{3,4}$ & 39 & 32.9 \\
\hline Nelore $^{4}$ & & 36.7 \\
\hline $\mathrm{HF}^{4}$ & & 22.7 \\
\hline Hereford $^{3}$ & 75 & \\
\hline Charolaise $^{3}$ & 53 & \\
\hline \multicolumn{3}{|l|}{ Storage method ${ }^{2}$} \\
\hline Fresh & 49.3 & 39 \\
\hline Frozen & 36.8 & 32.9 \\
\hline \multicolumn{3}{|l|}{ Sorting process ${ }^{5}$} \\
\hline Sorter & 40 & 37.3 \\
\hline not sorter & 48.7 & 42.3 \\
\hline \multicolumn{3}{|l|}{ Biopsy $^{6}$} \\
\hline Biopsied & 54.2 & 26.4 \\
\hline not biopsied & 55.9 & 19.8 \\
\hline
\end{tabular}


One of the strategies to improve the survival of IVP embryos is to modify the composition of the media in order to approximate the parameters of the microenvironment of the culture to the conditions in which the embryo develops in vivo. Under physiological conditions, endometrial cells produce growth factors, cytokines, hormones and other regulatory molecules. Hyaluronate, Insulin Growth Factors (IGF-1, IGF-2), Colony Stimulating Factor 2 (CSF-2), Fibroblast Growth Factor (bFGF), Transforming Growth Factor (TGF- $\beta 1$ ), Granulocyte and Macrophage Colony Stimulating Factor (GM-CSF) and Leukemia Inhibiting Factor (LIF) are among the specific molecules whose supplementation may increase the survival of transferred embryos, both fresh and vitrified [31-34]. It has also been shown that a medium supplementation with $40 \mathrm{ug} / \mathrm{ml}$ of heparin in the case of embryo production using sexed semen yields a pregnancy rate similar to that of conventional embryo transfer [23]. Taking into account the increased susceptibility to cryopreservation of IVP embryos caused by higher concentration of lipids in their structure, Sanches et al. investigated the effect of lipolytic factor (forslokine) on culture media. It was shown that forslokine supplementation caused an increase in the pregnancy rate in comparison to the control group (48.8\% vs. $18.5 \%$ ) [25].

\section{Factors related to embryo transfer procedure}

Spell et al. [15] and Frade et al. [35] report that strong expression of the heat symptoms positively correlates with progesterone levels and the conception rates. However, opinions on CR after embryo transfer after natural and synchronized heat are divided. Some authors indicate that the higher percentage of pregnancies is obtained after natural heat than that induced by prostaglandin (PGF $2 \alpha$ ) or its analogues [36,37]. Problems associated with a poorly expressed heat observation can be eliminated by using timed embryo transfer (TET) [38,39]. It has been shown that the use of optimised synchronisation programmes results in a significant increase in the number of recipients available for transfer [40] and correlates with the amount of pregnancies per transfer session [7], as well as has a positive effect on the value of the conception rate in recipient cows, making TET suitable for transfer of both fresh (IVP-F) and vitrified (IVP-V) in vitro produced embryos [41].

According to some authors, the asynchronous, in other words, the difference in the time of occurrence of synchronized heat between donor and recipient, observed in field conditions, has no significant influence on the results of CR in recipients $[6,15,42]$. However, opinion of others, an asynchronism has a significant effect on conception rates $[9,37,43]$. According to Misra et al. [37], significant differences in the percentage of pregnancies occur at \pm 12 hours asynchrony. Donaldson [44] reported, that the differences in the CR for asynchronous animals of -24 and +24 hours were $6.9 \%$ and $4.8 \%$, respectively, while in the case of -36 and +36 hours asynchronous - $4.7 \%$ and $9.8 \%$, respectively. According to more recent studies, the conception rates for \pm 30 hours asynchrony ranges from 36 to 50\%[9]. Ledgard et al. [43], transferring 7-day-old blastocysts produced in vitro to synchronized ( 7 days after heat) and unsynchronized (5 or 9 days after heat) recipients, obtained the highest percentage of pregnancies in the group of recipients in whom asynchronization was +48 hours (Table 2). Additionally, the analysis of the recipients' histotroph proteom showed the highest expression of protein factors facilitating embryo implantation on the 9 th day of the cycle.

The functional status of the recipient's uterus is also mentioned as an important factor that may cause the failure of ET procedure. The intensified contractility of this organ may lead to immediate or delayed expulsion of embryos. The presence of cervical mucus, which may clog the end of the catheter or surround the embryo and keep it in the cervix during the withdrawal of equipment, is also one of the factors determining the effectiveness of the procedure. Moini et al. [45] pointed out the relationship between the degree of cervical stenosis due to mucus filling and the results of embryo transfer. The removal of the clog from the cervical lumen increased the probability of implantation and favoured an improvement in pregnancy rate by $1 / 3$.

The prolonged time of cervical catheterization, usually caused by acute uterine and cervical angulation, cervical stenosis or anatomical distortion of the cervical canal, may significantly hinder the placement of embryos in the uterine cavity [16],[46]. It is also more difficult to penetrate the cervix in the case of Bos indicus cows, in which the organ is longer than in Bos taurus cows $[47,48]$. The relationship between the degree of difficulty during embryo transfer procedure and its effectiveness was studied by Roper et al. [16]. The study was conducted on a three-stage scale based on the opinion of ET technicians, in which "1" meant "easy", "2" meant "moderate" and "3" meant "difficult" embryo transfer. The results of conception rates in the group of animals in which the ET procedure was found to be easy were significantly higher than in the other two (Tab. 2). A significant linear relationship between the time of the transcervical insemination gun passage (TTIGP) to the place of embryo deposition in the horn and the results of conception was observed. The longer the manipulation time, the fewer cows were pregnant. When TTIGP was over a minute, the percentage of pregnant females was $50 \%$ lower than in the case of manipulation lasting shorter [49]. More recent studies by Roper et al. confirm earlier reports [16]. The highest percent- 
age of pregnancies was observed in cows from the group where the total time of cervical catheterization and embryo deposition was 6-9 minutes, while in cows where the procedure lasted longer (10-13 minutes and 14-25 minutes) the CR were relatively lower (Tab. 2) [16].

Worse results of pregnancies are obtained in the case of embryo transfer in cows than in the case of heifers $[18,50]$. It is suspected that one of the reasons is a longer TTIGP and larger uterus size [18,51]. Similarly, the multiple use of a female as a recipient reduces the likelihood of pregnancy after embryo transfer. The mechanism of this phenomenon is not entirely clear and it is difficult to explain it only by the relation of the time of gun passage through the cervix. Manipulations within the cervix, especially its broadening, cause an increased concentration of prostaglandin metabolites, shortened luteal phase, weakened secretory functions of the corpus luteum, and increased synthesis of oxytocin, which may lead to embryo loss [52]. Prolonged cervical manipulation causes stress and its consequences - increased concentrations of ACTH and cortisol [53,54].

The relationship between the place of embryo deposition in the uterus relative to the localization of the corpus luteum and the results of conception was also discussed $[13,17,18,37,54-56]$. The placement of the embryo ipsilaterally to the corpus luteum allows to obtain higher pregnancy rates in comparison with contraternal deposition (Tab. 2) [13]. Sanchez et al. analyzing transcriptomes of uterine horns located ipsilaterally and contraterally to CL showed that there are differences in the expression of endometrial genes, but they are not correlated with the pregnancy survival up to 14 days after conception [55]. Trigal et al. confirmed that there are disproportions in the concentrations of progesterone, glucose and other components essential for the embryonic survival due to the asymmetry of the reproductive system, preferring the left horn of the uterus [56]. However, field studies did not show that the ipsilateral introduction of the embryo into the left horn of the uterus would guarantee a significantly higher rate of conception than when the right horn was in the ipsilateral position (53.2 vs. 51.0\%) [56].

The depth of embryo insertion into the uterus may also influence the transfer effectiveness. The results of embryo placement were significantly higher in recipients in which embryos were deposited deep in the horn of the uterus than in those in which embryos were placed in the middle of the horn or in the area of the uterus body (43\% vs. $31 \%$ and $24 \%$ respectively) (Tab. 2 ) [16,54].

\section{Individual characteristics of donors and recipients}

The percentage of pregnant recipients with easily palpable corpus luteum is higher than in those with less developed CL $[15,57]$. This is related to the level of progesterone recorded in the recipients. The

TABLE 2 Influence of factors related to embryo transfer on the conception rates ( (own compilation based on: ${ }^{1}$ Ledgard et

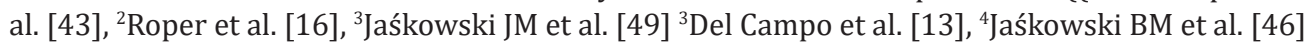

\begin{tabular}{c|c}
\hline \multicolumn{1}{c|}{ FACTOR } & CR \\
\hline \multicolumn{1}{c}{ Asynchrony ${ }^{1}$} & $25 \%$ \\
\hline none (7d) & $30 \%$ \\
\hline Embryo transfer difficulty ${ }^{2}$ & $40 \%$ \\
\hline Moderate & \\
\hline Difficult & $43 \%$ \\
\hline TTIGP ${ }^{3}$ & $32 \%$ \\
\hline 10-60s & $18 \%$ \\
\hline$>60$ s & $53.4 \%$ \\
\hline Depth of embryo deposition ${ }^{2} \quad$ Deep in the horn & $20.4 \%$ \\
\hline In the middle part of uterus horn & \\
\hline In the uterus body & $43 \%$ \\
\hline Ipsilaterally & $31 \%$ \\
\hline Localization of the CL relative to the follicle & $24 \%$ \\
\hline Contrlaterally & \\
\hline Structure of corpus luteum ${ }^{4} \quad$ Cavitary CL & $65 \%$ \\
\hline Compact CL & $33 \%$ \\
\hline
\end{tabular}


concentration of progesterone in the blood of females on the day of embryo transfer and 7 days later correlates with the conception rates [58],[59]. The higher the progesterone level on the day of embryo transfer and the lower the estradiol level, the better the results of embryo transfer [59]. There is a significant positive correlation between the degree of development of the corpus luteum measured by its volume and the level of progesterone [46,60-62]. It was shown that with a blood progesterone concentration above $2-2.5 \mathrm{ng} / \mathrm{ml}$ on the day before or on the day of embryo transfer, a higher pregnancy rate was obtained after fresh embryo transfer compared to recipients with a lower progesterone concentration than indicated $[8,12,63]$. Kenyon et al. [64] state the minimum level of progesterone necessary to keep pregnancy in recipients. Between 0 and 7 days after insemination it should amount to 2.71 $\mathrm{ng} / \mathrm{ml}$, and between 8-14 days after insemination$1.48 \mathrm{ng} / \mathrm{ml}$. According to Jaśkowski et al. [65,66], the type of corpus luteum is also a significant factor correlated with the recorded progesterone levels. In recipients with cavernous structure of the corpus luteum, both $\mathrm{P} 4$ concentrations and CR were higher than in females with solid structure $(12.1+/-3.58$ and $8.1+/ 3.96$ for P4 and $37.3 \%$ and $30.4 \%$ for CR, respectively). Some authors [15] do not share this theory, attributing the high results of embryo transfer only to the precision of heat detection. The presence of the first wave follicle may be relevant for the conception rate. In addition to its increased size, the dominant follicle is distinguished from secondary follicles by its ability to produce more oestradiol, maintain low concentrations of intrafollicular binding proteins of insulin-like growth factor $-2,-4$ and -5 and folistatin and increase free intrafollicular IGF-I concentrations [67].

The results of research on the dependence of fertility rates of cows on the level of milk production indicate that in the case of donor cows with high milk production in the period preceding the superovulation protocol, the probability of fertilization the recipient after ET was lower than in the case of donor cows with significantly lower milk production before embryo flushing $[49,68,69]$. This relationship was explained by the lower quality of embryos collected from donors with high milk production and increased likelihood of early embryo mortality. Each subsequent day of lactation in donors increased the chances of fertilization the recipient [70].

In a study by Skrzypek et al. [71] a strong correlation between inflammation of the udder and cow's reproductive functions was found. It is the consequence of changes in the hormonal system, resulting in disorders in the sexual cycle and ovulation and early embryo mortality. Risco et al. [72] noted that the risk of losing pregnancy was 2.7 times higher in the case of udder inflammation up to 54 days after conception compared to cows who did not have any mastitis cases during this period.
Some authors correlate the transfer results with the age of the recipients [54]. The CR were found to be higher in recipients older than 525 days [17]. Ferraz et al. recorded significantly lower conception rates in multiparae than in primiparae and heifers (31.6\% vs. $37.8 \%$ vs. $42 \%$, respectively) [6]. A similar pattern was observed in Mikkola et al. in both conventional and sexed semen (57.8 and 54.8\% for heifers, 17.7 and $18.2 \%$ for the primiparae and 24.5 and $27 \%$ for multiparae, respectively) [24].

A lot of attention was also focused on the influence of the condition of recipients (BCS) on the effectiveness of embryotransfer. It was shown that the pregnancy rates were significantly higher in recipients whose condition was evaluated at 3 and 4 (on a 5-point scale) than in those whose condition was assessed at 1, 2 or 5 points $[39,73]$. Fernandes et al. [74] analyzed the effect of daily weight gain of recipients on the effectiveness of pregnancy maintenance obtained from IVP embryos. It was shown that the percentage of pregnancies increases with daily weight gain to $350 \mathrm{~g} /$ day, which suggests that this is the threshold for obtaining an optimal pregnancy rate in recipients. In addition, the assessment of daily weight gain allows the detection of even minimal fluctuations that make this method more sensitive than the evaluation of animal condition on the basis of BCS.

\section{Environmental factors}

The demand for nutrients in lactating cows rises with the increase in production, which may result in a negative energy balance. This has a significant impact on the hormonal management of the female and may cause impairment of its condition and lowering of progesterone level in blood, and consequently result in deterioration of conditions of embryo implantation in the uterus [36,75-77].

Reduced effectiveness of embryo transfer may also be associated with simultaneous occurrence of lameness or mastitis. Mental stress associated with changes in technological groups, transport or treatment of animals by the personnel also leads to lower pregnancy rates $[76,78,79]$.

There are some differences between the CR as a result of embryo transfer depending on the period of time during which ET was performed [80]. It was shown that the results of embryo transfer in summer were worse than those obtained in spring and winter $[17,37,79,81]$. Inappropriate climatic conditions - too high temperature and environmental hyperthermia - may lead to hormonal disorders and increased embryonic mortality in the second week of pregnancy $[17,78,79,82,83]$. High temperature and humidity index (THI) $(\geq 80$ ) had a negative effect on the results of embryo transfer in the 8th, 7th and 6th day after heat [6]. Nabenishi et al. [84] noted differences between CR in Japanese black and HF cattle in different seasons of the year. In Holstein-Friesian cattle the conception rates in 
August-October were lower than in other months. CR for Black Japanese recipients was the lowest between December and January. These results may suggest that cattle for fattening are less exposed to the negative effects of thermal stress. Fertility reduction after embryo transfer in the hot season is lower than after insemination [41]. For this reason, transfer of IVP embryos during seasonal heat may be a way to avoid fertility depression [85]. Also, the use of in vitro embryos obtained after insemination with sorted semen improves the conception rates in cows exposed to heat stress [86].

Lower conception rates and increased embryo mortality may also be due to infection with pathogens, among which the among which bovine viral diarrhea virus (BVDV) is a particular nuisance [1].

\section{Conclusions}

Many years of research and population observations have allowed to identify the most important factors influencing the effectiveness of embryo transfer in cattle. This allows for the proper selection of embryos and their recipients, as well as setting the optimal date of transfer. Not without significance for the efficiency of ET also seem to be the efforts aimed at improving the technical components of the transfer - nutrient composition, freezing protocols and manipulation during embryo transfer. The conscious minimization of these factors has significant economic implications, favouring the increase of ET efficiency.

\section{Ethical approval}

The conducted research is not related to either human or animal use.

\section{Acknowledgements \\ Not applicable.}

\section{Corresponding author}

Maria Wieczorkiewicz, Department of Basic and Preclinical Sciences, Institute of Veterinary Medicine, Faculty of Biological and Veterinary Sciences, Nicolaus Copernicus University, 7 Gagarina Street 87-100 Toruń, Poland, tel.: +48693-809-673, e-mail: maria. wieczorkiewicz@umk.pl.

\section{Conflict of interest statement}

The authors declare they have no conflict of interest.

\section{References}

1. Givens MD, Marley SD. Approaches to biosecurity in bovine embryo transfer programs. Theriogenology. 2008;69(1); DOI:10.1016/j. theriogenology.2007.09.009.

2. Rowe R. F., Del Campo M. R., Crister J. K., Ginther O. J. Embryo transfer in cattle: nonsurgical transfer. Am J Vet Res. 1980;40:1024-1028.

3. Mikkola M. Commercial Embryo Transfer Activity in Europe. In: 34th Annual Meeting A.E.T.E. Nantes; 2018.

4. Feres LF, Siqueira LGB, Palhao MP, dos Santos LL, Brandao FZ, Viana JHM. Likelihood of pregnancy after the transfer of embryos derived from follicle aspiration and in vitro embryo production sessions with different relative efficiencies. Anim Reprod Sci. 2018;193:165-170 DOI:10.1016/j.anireprosci.2018.04.065.

5. Pontes JHF, Silva KCF, Basso AC, Rigo AG, Ferreira CR, Santos GMG, Sanches BV, Porcionato JPF, Vieira PHS, Faifer FS, Sterza FAM, Schenk $\mathrm{JL}$, Seneda MM. Large-scale in vitro embryo production and pregnancy rates from Bos taurus, Bos indicus, and indicus-taurus dairy cows using sexed sperm. Theriogenology. 2010;74(8); DOI:10.1016/j. theriogenology.2010.06.004.

6. Ferraz PA, Burnley C, Karanja J, Viera-Neto A, Santos JEP, Chebel RC Galvão KN. Factors affecting the success of a large embryo transfer program in Holstein cattle in a commercial herd in the southeast region of the United States. Theriogenology. 2016;86(7); DOI:10.1016/j. theriogenology.2016.05.032.

7. Chebel RC, Demétrio DGB, Metzger J. Factors affecting success of embryo collection and transfer in large dairy herds. Theriogenology. 2008;69(1); DOI:10.1016/j.theriogenology.2007.09.008.

8. Nishigai M. The Development and Prevalence of the Transfer Technique for Frozen-Thawed Embryos of Japanese Black Beef Cattle in Tochigi Prefecture. J Reprod Dev. 2003;49(1); DOI:10.1262/jrd.49.23.

9. Rodrigues M, Bonotto A, Acosta D, Boligon A, Corrêa M, Brauner C. Effect of oestrous synchrony between embryo donors and recipients, embryo quality and state on the pregnancy rate in beef cattle. Reprod Domest Anim. 2018;53(1):152-156; DOI:10.1111/rda.13084.

10. Lindner GM, Wright RW. Bovine embryo morphology and evaluation Theriogenology. 1983;20(4); DOI:10.1016/0093-691X(83)90201-7.

11. Znaniecki R. Czynniki określające powodzenie transferu zarodków u krów mlecznych na Żuławach Wiślanych. 1996.

12. Niemann H, Sacher B, Elsaesser F. Pregnancy rates relative to recipient plasma progesterone levels on the day of nonsurgical transfer of frozen/thawed bovine embryos. Theriogenology. 1985;23(4); DOI:10.1016/0093-691X(85)90197-9.

13. Del Campo MR, Rowe RF, Chaichareon D, Ginther OJ. Effect of the relative locations of embryo and corpus luteum on embryo survival in cattle. Reprod Nutr Développement. 1983;23(2A); DOI:10.1051/ rnd:19830214.

14. Erdem H, Karasahin T, Alkan H, Dursun S, Satilmis F, Guler M. Effect of embryo quality and developmental stages on pregnancy rate during fresh embryo transfer in beef heifers. Trop Anim Health Prod. 2020;52(5); DOI:10.1007/s11250-020-02287-6.

15. Spell AR, Beal WE, Corah LR, Lamb GC. Evaluating recipient and embryo factors that affect pregnancy rates of embryo transfer in beef cattle. Theriogenology. 2001;56(2); DOI:10.1016/S0093-691X(01)00563-5.

16. Roper DA, Schrick FN, Edwards JL, Hopkins FM, Prado TM, Wilkerson JB, Saxton AM, Young CD, Smith WB. Factors in cattle affecting embryo transfer pregnancies in recipient animals. Anim Reprod Sci. 2018;199:79-83; DOI:10.1016/j.anireprosci.2018.11.001.

17. Weaver LD, Galland J, Sosnik U, Cowen P. Factors Affecting Embryo Transfer Success in Recipient Heifers Under Field Conditions. J Dairy Sci. 1986;69(10); DOI:10.3168/jds.S0022-0302(86)80718-4.

18. Znaniecki R, Jaśkowski JM, Znaniecka E. Wpływ niektórych czynników na wyniki zacieleń u jałowic biorczyń świeżych zarodków. Med Weter. 1998;54:550-553.

19. Hasler JF. Factors affecting frozen and fresh embryo transfer pregnancy rates in cattle. Theriogenology. 2001;56(9); DOI:10.1016/ S0093-691X(01)00643-4.

20. Arreseigor CJ, Filipiak Y, Avelino AB, Ibarreche M., Paredes J., Pereira AE, Arreseigor K, Avelino AB. Pregnancy rates from different cattle breed embryos produced in vitro in a commercial program (part 1).

21. Donaldson LE. Cattle breed as a source of variation in embryo transfer Theriogenology. 1984;21(6); DOI:10.1016/0093-691X(84)90396-0.

22. Do VH, Catt S, Amaya G, Batsiokis M, Walton S, Taylor-Robinson AW. Comparison of pregnancy in cattle when non-vitrified and vitrified in vitro-derived embryos are transferred into recipients. Theriogenology. 2018;120; DOI:10.1016/j.theriogenology.2018.07.027.

23. An L-Y, Chaubal SA, Liu Y, Chen Y, Nedambale TL, Xu J, Xue F, Moreno JF, Tao S, Presicce GA, Du F. Significant heparin effect on bovine embryo development during sexed in vitro fertilization. J Reprod Dev. 2017;63(2):175-183; DOI:10.1262/jrd.2016-142.

24. Mikkola M, Andersson M, Taponen J. Transfer of cattle embryos produced with sex-sorted semen results in impaired pregnancy rate and increased male calf mortality. Theriogenology. 2015;84(7):1118-1122; DOI:10.1016/j.theriogenology.2015.06.012.

25. Sanches BV, Marinho LSR, Filho BDO, Pontes JHF, Basso AC, Meirinhos MLG, Silva-Santos KC, Ferreira CR, Seneda MM. Cryosurvival and pregnancy rates after exposure of IVF-derived Bos indicus embryos to forskolin before vitrification. Theriogenology. 2013;80(4):372-377; DOI:10.1016/j.theriogenology.2013.04.026.

26. Gutnisky C, Alvarez GM, Cetica PD, Dalvit GC. Evaluation of the Cryotech Vitrification Kit for bovine embryos. Cryobiology. 2013;67(3); DOI:10.1016/j.cryobiol.2013.08.006.

27. Shea B. Determining the sex of bovine embryos using polymerase chain reaction results: A six-year retrospective study. Theriogenology. 1999;51(4); D0I:10.1016/S0093-691X(99)00030-8.

28. Thibier M, Nibart M. The sexing of bovine embryos in the field. Theriogenology. 1995;43(1); DOI:10.1016/0093-691X(94)00008-I. 
29. Oliveira CS, Romano Quintão CC, de Freitas C, dos Reis Camargo AJ, Serapião RV, de Almeida Camargo LS. Post implantation development reveals that biopsy procedure can segregate "healthy" from "unhealthy" bovine embryos and prevent miscarriages. Anim Reprod Sci. 2017;184:51-58; DOI:10.1016/j.anireprosci.2017.06.016.

30. de Sousa RV, da Silva Cardoso CR, Butzke G, Dode MAN, Rumpf R, Franco MM. Biopsy of bovine embryos produced in vivo and in vitro does not affect pregnancy rates. Theriogenology. 2017;90; DOI:10.1016/j. theriogenology.2016.11.003.

31. Block J, Bonilla L, Hansen PJ. Effect of addition of hyaluronan to embryo culture medium on survival of bovine embryos in vitro following vitrification and establishment of pregnancy after transfer to recipients. Theriogenology. 2009;71(7):1063-1071; DOI:10.1016/j. theriogenology.2008.11.007.

32. Block J, Hansen PJ, Loureiro B, Bonilla L. Improving post-transfer survival of bovine embryos produced in vitro: Actions of insulin-like growth factor-1, colony stimulating factor-2 and hyaluronan. Theriogenology. 2011;76(9):1602-1609; DOI:10.1016/j.theriogenology.2011.07.025

33. Neira JA, Tainturier D, Peña MA, Martal J. Effect of the association of IGF-I, IGF-II, bFGF, TGF- $\beta 1$, GM-CSF, and LIF on the development of bovine embryos produced in vitro. Theriogenology. 2010;73(5):595-604; D0I:10.1016/j.theriogenology.2009.10.015.

34. Moreno D, Neira A, Dubreil L, Liegeois L, Destrumelle S, Michaud S, Thorin C, Briand-Amirat L, Bencharif D, Tainturier D. In vitro bovine embryo production in a synthetic medium: Embryo development, cryosurvival, and establishment of pregnancy. Theriogenology. 2015;84(7):10531060; DOI:10.1016/j.theriogenology.2015.04.014.

35. Frade MC, Frade C, Cordeiro MB, Sá Filho MF de, Mesquita FS, Nogueira G de P, Binelli M, Membrive CMB. Manifestation of estrous behavior and subsequent progesterone concentration at timed-embryo transfer in cattle are positively associated with pregnancy success of recipients. Anim Reprod Sci. 2014;151(3-4); DOI:10.1016/j.anireprosci.2014.09.005.

36. Butler W. Nutritional interactions with reproductive performance in dairy cattle. Anim Reprod Sci. 2000;60-61; DOI:10.1016/ S0378-4320(00)00076-2.

37. Misra AK, Mutha Rao M, Kasiraj R, Ranga Reddy NS, Pant HC. Factors affecting pregnancy rate following nonsurgical embryo transfer in buffalo (Bubalus bubalis): A retrospective study. Theriogenology. 1999;52(1); DOI:10.1016/S0093-691X(99)00105-3.

38. Baruselli PS, Ferreira RM, Filho MFS, Nasser LFT, Rodrigues CA, Bó GA Bovine embryo transfer recipient synchronisation and management in tropical environments. Reprod Fertil Dev. 2010;22(1); D0I:10.1071/ RD09214.

39. Jones AL, Lamb GC. Nutrition, synchronization, and management of beef embryo transfer recipients. Theriogenology. 2008;69(1); DOI:10.1016/j theriogenology.2007.09.004.

40. Rabaglino MB, Risco CA, Thatcher M-J, Lima F, Santos JEP, Thatcher WW. Use of a five-day progesterone-based timed AI protocol to determine if flunixin meglumine improves pregnancy per timed AI in dairy heifers. Theriogenology. 2010;73(9); DOI:10.1016/j. theriogenology.2009.12.012.

41. Al-Katanani Y., Drost M, Monson R., Rutledge J., Krininger C., Block J, Thatcher W., Hansen P. Pregnancy rates following timed embryo transfer with fresh or vitrified in vitro produced embryos in lactating dairy cows under heat stress conditions. Theriogenology. 2002;58(1); DOI:10.1016/S0093-691X(02)00916-0.

42. Lamb C. Factors affecting an embryo an embryo transfer program. . In Proceedings of Applied Reproductive Strategies in Beef Cattle. Nevada; 2005:223-231.

43. Ledgard AM, Berg MC, McMillan WH, Smolenski G, Peterson AJ. Effect of asynchronous transfer on bovine embryonic development and relationship with early cycle uterine proteome profiles. Reprod Fertil Dev. 2012;24(7):962; DOI:10.1071/RD11225.

44. Donaldson L. Matching of embryo stages and grades with recipient oestrous synchrony in bovine embryo transfer. Vet Rec. 1985;117(19); DOI:10.1136/vr.117.19.489.

45. Moini A, Kiani K, Bahmanbadi A, Akhoond M, Akhlaghi A. Improvement in pregnancy rate by removal of cervical discharge prior to embryo transfer in ICSI cycles: A randomised clinical trial. Aust New Zeal J Obstet Gynaecol. 2011;51(4); DOI:10.1111/j.1479-828X.2011.01318.x

46. Jaśkowski BM, Gehrke M, Woźna MP, Urbaniak K, Jaśkowski JM. The effect of the presence or absence of a cavity in the corpus luteum on progesterone concentrations and pregnancy rate in heifers following embryo transfer. In: 33rd Scientific Meeting of the AETE. Bath; 2017:93-undefined.

47. Bello A, Adamub YA, Umaruc MA, Garbad S, Abdullahid AU, Adamud MK, Saidue B, Ukashatuf S, Henaa SA, Mahmudag A. Morphometric analysis of the reproductive system of African zebu cattle. Sci J Zool. 2012;1:31-36.
48. Khaton R, Sarder MJU, Gofur MR. Biometrical Studies of Reproductive Organs of Dairy Cows of Different Genotypes in Bangladesh. Asian J Anim Sci. 2015;9(6); DOI:10.3923/ajas.2015.388.395.

49. Jaśkowski JM, Olechnowicz J, Nowak W. Niektóre przyczyny obniżającej się płodności u krów mlecznych. Med Weter. 2006;62:385-389;

50. Urbaniak K. Wpływ egzo- i endogennego progesteronu na wyniki zacieleń u krów biorczyń zarodków. 2000.

51. Jaśkowski J, Urbaniak K, Antosik P, Włodarczyk R. The influence of transfer gun passage time through the uterine cervix on pregnancy rate in recipient heifers. Acta Vet Hung. 2010;58(1); D0I:10.1556/ avet.58.2010.1.13

52. Koblischke P, Budik S, Müller J, Aurich C. Practical Experience with the Treatment of Recipient Mares with a Non-Steroidal Anti-Inflammatory Drug in an Equine Embryo Transfer Programme. Reprod Domest Anim. 2010;45(6); DOI:10.1111/j.1439-0531.2009.01486.x.

53. Cooke RG, Benhaj KM. Effects of ACTH and cortisol on luteolysis in the ewe. Anim. Reprod. Sci. 1989, 20, 201-211. Anim Reprod Sci. 1989;20:201-211.

54. Mollo A, Lora M, Faustini M, Romagnoli S, Cairoli F. Some factors affecting embryo transfer success in dairy cows. J Anim Vet Adv. 2007;6:496-499.

55. Sánchez JM, Passaro C, Forde N, Browne JA, Behura SK, Fernández-Fuertes B, Mathew DJ, Kelly AK, Butler ST, Spencer TE, Lonergan P. Do differences in the endometrial transcriptome between uterine horns ipsilateral and contralateral to the corpus luteum influence conceptus growth to day 14 in cattle?†. Biol Reprod. August 2018; D0I:10.1093/ biolre/ioy185.

56. Trigal B, Díez C, Muñoz M, Caamaño JN, Goyache F, Correia-Alvarez E, Corrales FJ, Mora MI, Carrocera S, Martin D, Gómez E. Elements of functional genital asymmetry in the cow. Reprod Fertil Dev. 2014;26(4); DOI:10.1071/RD13056.

57. Żychlińska J, Gil Z, Słoniewski K. Zależność pomiędzy stopniem rozwoju ciałka żółtego i poziomem progesteronu a wynikami zacieleń biorczyń zarodków. Med Weter. 2005;61:1175-1176.

58. Demetrio DGB, Santos RM, Demetrio CGB, Vasconcelos JLM. Factors Affecting Conception Rates Following Artificial Insemination or Embryo Transfer in Lactating Holstein Cows. J Dairy Sci. 2007;90(11); DOI:10.3168/jds.2007-0223.

59. Nishigai M, Kamomae H, Tanaka T, Kaneda Y. The Relationship of Blood Progesterone and Estrogen Concentrations on the Day Before and the Day of Frozen-Thawed Embryo Transfer to Pregnancy Rate in Japanese Black Beef Cattle. J Reprod Dev. 2000;46(4); DOI:10.1262/jrd.46.235.

60. Alegre B, Tejero J, Gomez C, Gonzalez-Montana JR, Alonso ME. TJCDF, Tejerina J. C. D. F. Correlations between the volumene of the corpus luteum and plasma concentration of progesterone in the estrus cycle of the cow. In: Proc. 29th. Buiatric Congress, Dublin, Ireland, 3-8 July 2016. Dublin; 2016:584-undefined.

61. Lonergan P, Fair T, Corcoran D, Evans ACO. Effect of culture environment on gene expression and developmental characteristics in IVF-derived embryos. Theriogenology. 2006;65(1):137-152; DOI:10.1016/j. theriogenology.2005.09.028.

62. Urbaniak K, Jackowska M, Woźna M, Włodarek J, Jaśkowski JM. Rozmiary i struktura ciałka żółtego a wyniki zacieleń u jałowic biorczyń zarodków. In: XIV Kongres PTNW. Wrocław; 2012:242-242.

63. Nishigai M, Kamomae H, Tanaka T, Kaneda Y. Improvement of pregnancy rate in Japanese Black cows by administration of hCG to recipients of transferred frozen-thawed embryos. Theriogenology. 2002;58(8); DOI:10.1016/S0093-691X(02)01062-2.

64. Kenyon AG, Mendonça LGD, Lopes G, Lima JR, Santos JEP, Chebel RC. Minimal progesterone concentration required for embryo survival after embryo transfer in lactating Holstein cows. Anim Reprod Sci. 2013;136(4); DOI:10.1016/j.anireprosci.2012.10.014.

65. Jaśkowski BM. Corpus luteum with a cavity in cattle: An overview of past and present knowledge. Med Weter. 2019;75(02); DOI:10.21521/ mw.6234

66. Jaśkowski BM, Bostedt H, Gehrke M, Jaśkowski JM. Ultrasound Characteristics of the Cavitary Corpus Luteum after Oestrus Synchronization in Heifers in Relation to the Results of Embryo Transfer. Animals. 2021;11(6); DOI:10.3390/ani11061706.

67. Diskin M., Austin E., Roche J. Exogenous hormonal manipulation of ovarian activity in cattle. Domest Anim Endocrinol. 2002;23(1-2); DOI:10.1016/S0739-7240(02)00158-3.

68. Lucy MC. Reproductive Loss in High-Producing Dairy Cattle: Where Will It End? J Dairy Sci. 2001;84(6); DOI:10.3168/jds.S0022-0302(01)70158-0.

69. Walton JS, Martineau NA, Stubbings RB. Pregnancy rates in Holstein embryo transfer recipients: Effect of treatment with progesterone or clenbuterol and of natural versus induced cycles. Theriogenology. 1986;26(6); DOI:10.1016/0093-691X(86)90013-0.

70. Vasconcelos JLM, Sá Filho OG, Justolin PLT, Morelli P, Aragon FL, Veras MB, Soriano S. Effects of postbreeding gonadotropin treatments on 
conception rates of lactating dairy cows subjected to timed artificial insemination or embryo transfer in a tropical environment. J Dairy Sci. 2011;94(1); DOI:10.3168/jds.2010-3462.

71. Skrzypek R, Antkowiak I, Pytlewski J. Zależność między liczba komórek somatycznych w mleku a wskaźnikami płodności. Med Weter. 2007;63:1247-1250.

72. Risco CA, Donovan GA, Hernandez J. Clinical Mastitis Associated with Abortion in Dairy Cows. J Dairy Sci. 1999;82(8); DOI:10.3168/jds. S0022-0302(99)75397-X.

73. Mapletoft R. J. Bovine Embryo Transfer. In: Current Therapy in Theriogenology. II. Philadelphia: WB Saunders Co.; 1986:54-63.

74. Fernandes CA de C, Palhao MP, Figueiredo ACS, Ribeiro JR, e Silva FF, Viana JHM. Weight gain potential affects pregnancy rates in bovine embryo recipients raised under pasture conditions. Trop Anim Health Prod. 2016;48(1):103-107; DOI:10.1007/s11250-015-0926-0.

75. Broadbent PJ, Stewart M, Dolman DF. Recipient management and embryo transfer. Theriogenology. 1991;35(1); DOI:10.1016/0093-691X(91)90152-4.

76. Jaśkowski JM, Zbylut J, Urbaniak K. Wpływ stresu adaptacyjnego na wyniki zacieleń u jałowic biorczyń zarodków. Życie Weter. 1998;73:273-273.

77. Jaśkowski JM, Gehrke M, Nowak T, Woźna M. Transfer zarodków u zwierząt - aktualna sytuacja. In: Biotechniki Stosowane w Rozrodzie Zwierząt Gospodarskich i Koni. Poznań: Wyd. UP; 2017:25-35.

78. Dobson H, TebbleJE, Smith RF, Ward WR. Is stress reallyall that important? Theriogenology. 2001;55(1); DOI:10.1016/S0093-691X(00)00446-5.

79. Drost M, Ambrose JD, Thatcher M-J, Cantrell CK, Wolfsdorf KE, Hasler JF, Thatcher WW. Conception rates after artificial insemination or embryo transfer in lactating dairy cows during summer in florida. Theriogenology. 1999;52(7); DOI:10.1016/S0093-691X(99)00208-3.

80. Hasler JF, McCauley AD, Lathrop WF, Foote RH. Effect of donor-embryo-recipient interactions on pregnancy rate in a large-scale bovine embryo transfer program. Theriogenology. 1987;27(1) DOI:10.1016/0093-691X(87)90075-6.

81. Kasimanickam R, Schroeder S, Assay M, Kasimanickam V, Moore D, Gay J, Whittier W. Influence of Temperament Score and Handling Facility on Stress, Reproductive Hormone Concentrations, and Fixed Time Al Pregnancy Rates in Beef Heifers. Reprod Domest Anim. 2014;49(5); DOI:10.1111/rda.12368.

82. García-Ispierto I, López-Gatius F, Santolaria P, Yániz JL, Nogareda C, López-Béjar M, De Rensis F. Relationship between heat stress during the peri-implantation period and early fetal loss in dairy cattle. Theriogenology. 2006;65(4); DOI:10.1016/j.theriogenology.2005.06.011.

83. Putney DJ, Thatcher WW, Drost M, Wright JM, DeLorenzo MA. Influence of environmental temperature on reproductive performance of bovine embryo donors and recipients in the southwest region of the united states. Theriogenology. 1988;30(5); DOI:10.1016/S0093-691X(88)80053-0.

84. Nabenishi H, Sugino F, Konaka R, Yamazaki A. Conception rate of Holstein and Japanese Black cattle following embryo transfer in southwestern Japan. Anim Sci J. 2018;89(8):1073-1078; DOI:10.1111/asj.13042.

85. Ambrose JD, Drost M, Monson RL, Rutledge JJ, Leibfried-Rutledge ML, Thatcher M-J, Kassa T, Binelli M, Hansen PJ, Chenoweth PJ, Thatcher WW. Efficacy of Timed Embryo Transfer with Fresh and Frozen In Vitro Produced Embryos to Increase Pregnancy Rates in Heat-Stressed Dairy Cattle. J Dairy Sci. 1999;82(11); DOI:10.3168/jds.S0022-0302(99)75487-1.

86. Stevenson JS, Tiffany SM, Inskeep EK. Maintenance of Pregnancy in Dairy Cattle After Treatment with Human Chorionic Gonadotropin or Gonadotropin-Releasing Hormone. J Dairy Sci. 2008;91(8); DOI:10.3168/ jds.2008-1027. 